\title{
Beyond Violence
}




\title{
Abrahamic Dialogues Series
}

\author{
Chief Editor
}

David B. Burrell, C.S.C., The University of Notre Dame

\section{Editorial Board}

Ibrahim Abu-Rabi', Hartford Seminary

Susannah Heschel, Dartmouth College

Donald J. Moore, S.J., Fordham University 


\section{BEYOND VIOLENCE}

Religious Sources of Social Transformation in Judaism, Christianity, and Islam

Edited by JAmes L. HeFT, S.M.

Fordham University Press

New York • 2004 


\section{Copyright C 2004 Fordham University Press}

All rights reserved. No part of this publication may be reproduced, stored in a retrieval system, or transmitted in any form or by any means - electronic, mechanical, photocopy, recording, or any other-except for brief quotations in printed reviews, without the prior permission of the publisher.

The Abrahamic Dialogues Series, No. 1

ISSN $1548-4130$

Library of Congress Cataloging-in-Publication Data

Beyond violence : religious sources of social transformation in Judaism, Christianity, and Islam / edited by James L. Heft.-1st. ed.

p. cm.-(The Abrahamic dialogues series ; no. 1)

Includes bibliographical references and index.

ISBN 0-8232-2333-7 (hardcover)-ISBN 0-8232-2334-5 (pbk.)

1. Peace-Religious aspects-Congresses. 2.Violence-Religious aspectsCongresses. I. Heft, James. II. Series.

BL65.P4B49 2004

$201.76-\mathrm{dc} 22$

2004001737

Printed in the United States of America

$08070605 \quad 5432$

First edition 


\section{DEDICATION}

This volume contains the major papers given at an international conference titled "Beyond Violence: Religious Sources for Social Transformation." Held at the University of Southern California on May 5-7, 2003, the conference drew more than two hundred participants. Jews, Christians, and Muslims honestly and thoughtfully considered how their religious traditions could become greater forces for justice and peace. I dedicate this volume to those individuals who collaborated with $\mathrm{me}$ in cvery phase of planning: Mr. Dafer Dakhil of the Omar Ibn Al-Khattab Foundation, Dr. Reuven Firestone of Hebrew Union College-Jewish Institute of Religion, Dr. Donald E. Miller of the Center for Religion and Civic Culture at the University of Southern California, and Ms. Brie Loskota, the conference director who generously assisted in editing this volume. I dedicate this volume also to those who provided important support for the entire effort:Dr. Steven B. Sample, President of the University of Southern California; Dr. Joseph Aoun, Dean of the College of Letters, Arts and Sciences, USC; Dr. Lewis M. Barth, Dean of HUC-JIR, Los Angeles; and Mr. Edward P. Roski Jr., friend and supporter of the Institute for Advanced Catholic Studies.

Fr. James L. Heft, S.M.

November 16, 2003 
This page intentionally left blank 